Kaya-Kılıç, A. Ve Aslantürk, H. (2019). Evsizlerin Sosyo-Demografik Özellikleri ve Sokak Yaşam Deneyimleri: Antalya Örneği. Toplum ve Sosyal Hizmet, 30(2), 417-437.

Araştırma

Makale geliş tarihi: 31.03 .2019

Makale kabul tarihi: 07.05.2019

\title{
EVSIZLERIN SOSYO-DEMOGRAFIK ÖZELLIKLERI VE SOKAK YAŞAM DENEYIMLERI: ANTALYA ÖRNEĞi
}

\section{Socio-demographic Characteristics of Homeless People and Their Experiences of Living on the Streets: Antalya Sample}

\author{
Ayten KAYA KILIÇ* \\ Hüsnünur ASLANTÜRK** \\ * Dr. Öğretim Üyesi, Muğla Sıtkı Koçman Üniversitesi Seydikemer Uygulamalı Bilimler \\ Yüksekokulu, Sosyal Hizmet Bölümü, ORCID ID: 0000-0001-7884-7111 \\ ** Dr. Öğretim Üyesi, Kocaeli Üniversitesi, Sağlık Bilimleri Fakültesi, Sosyal Hizmet Bölümü, \\ ORCID ID: 0000-0002-8174-4970
}

\section{ÖZET}

Evsizlik, doğrudan ya da dolaylı olarak etkilenen insan sayısındaki artış ve diğer sosyal sorunlarla olan yapısal bağı nedeniyle tüm dünyada olduğu gibi ülkemizde de önemli bir sorun olarak görülmektedir. Evsiz bireylere yönelik planlanacak sosyal politikalarda ve sunulacak hizmet modellerinde öncelikle bu grubun özelliklerinin bilinmesi ve yaşam koşullarının anlaşılması gerekmektedir. Bu doğrultuda çalışmada evsizlerin sosyodemografik özelliklerinin ve sokak yaşam deneyimlerinin belirlenmesi amaçlandı. Genel tarama modelinde tasarlanan çalışmaya 2018 yılı içinde Antalya Eğitim ve Araştırma Hastanesi Sosyal Hizmet Birimi'ne başvuran, araştırmaya katılmaya gönüllü olan evsizler $(n=50)$ dahil edildi. Veriler 34 sorudan oluşan anket formu aracılığıyla toplandı. Çalışmanın sonucunda çalışmaya katılan evsiz bireylerin çoğunluğunun 45-59 yaş arasında, bekar, ilkokul mezunu erkeklerden oluştuğu görüldü. Sokak yaşamı öncesinde çoğunlukla aileleriyle birlikte yaşayan evsiz bireylerin, yine aynı dönemde ücretli bir işte çalıştıkları, dolayısıyla toplumsal yaşamın içinde oldukları anlaşıldı. Çoğunluğunun ekonomik nedenlerle sokakta yaşadığı, düzenli bir gelirlerinin ve sosyal güvencelerinin olmadığı; ihtiyaçlarını sosyal yardımlar, gönüllü insanların verdikleri ya da günlük işlerden elde ettikleri gelirle karşıladıkları 
sonucuna ulaşıldı. Çoğunlukla 5 yıl ve daha fazla süredir sokakta yaşayan evsiz bireylerin sokak yaşam tarzını kronikleştirdikleri, fiziksel ve ruhsal sağlık problemleri yaşadıkları ve sokakta yaşamlarını sürdürmekle ilgili çeşitli stratejiler geliştirdikleri görüldü. Genel olarak sokakta yaşamanın risklerinin farkında oldukları ve uygun koşullar sağlandığında sokakta yaşamaktan vazgeçebilecekleri anlaşıldı.

Anahtar Sözcükler: Evsiz, sosyo-demografik özellikler, sokak yaşam deneyimi,

\section{ABSTRACT}

Homelessness is an important problem in our country as it is in the whole world because of the increase in the number of people affected directly or indirectly by it and its structural link with other social problems. The characteristics of homeless people should be known and their living conditions should be understood in order to plan social policies for them and for the service models to be provided to them. Accordingly, this study aims to determine the sociodemographic characteristics of homeless people and their experiences of living on the streets. The study was designed at the general scanning model and it includes the homeless people $(n=50)$ who applied to the Social Services Unit of Antalya Training and Research Hospital in 2017-2018 and volunteered to participate in the study. The data were collected through a questionnaire containing 34 questions. At the end of the study, it was found that the majority of the participant homeless people is 45-59 years old, single, and primary school graduate males. In addition, it was understood that the homeless people who had lived mostly with their families before starting to live on the streets had salaried employment and therefore had been a part of the social life during this period of their lives. Besides, it was discovered that the majority of them lives on the streets due to financial reasons and doesn't have a regular income and social security; moreover, they cover their needs through social aids, the goods that volunteers provide them, or the incomes that they receive from daily jobs. This lifestyle of the homeless people who have lived on the streets for 5 years or more has become chronic, they suffer from physical and psychological health problems, and have developed several strategies for living on the streets. It is seen that they are aware of the risks of living on the streets in general and can stop living on the streets when the proper conditions are provided.

Key Words: Homeless, sociodemographic characteristics, experiences of living on the streets 


\section{Giriş}

Insanın hayatta kalması ve yaşamını sürdürmesi temel ihtiyaçlarının karşılanması ile doğrudan ilişkilidir. İhtiyaçlar hiyerarşisinin en alt basamağını oluşturan ve fiziksel intiyaçlar olarak değerlendirilen bu intiyaçlardan biri de barınmadır. Bu intiyacın karşılanmaması ya da karşılanamaması bireyi başta fiziksel olmak üzere ruhsal, sosyal ve duygusal açıdan etkileyen bir durum olarak karşımıza çıkmaktadır. Birçok farklı tanımı ve bileşeni olmakla birlikte genel olarak "evsizlik" olarak kavramsallaştııılan barınmadan yoksun olma durumu, günümüzde ortaya çıkış nedenleri ile birey ve toplum üzerindeki etkileri ile çok boyutlu olarak tartışılmaktadır.

Kentlerdeki nüfus artışına karşılık istihdam ve konut arzındaki yetersizlik kentlerin genel nüfusun ihtiyaçlarını karşılayamaz duruma gelmesine neden olmakta, yoksul insanlar gecekondu ve benzeri yerleri barınma yeri olarak seçmekte ve kendi kaderlerine terk edilmektedirler. Özellikle refah devletlerinde 1980'li yıllardan sonra uygulanan neo-liberal politikalar sonucunda düşük gelirli kişilerin konut intiyacının kamusal hizmet kapsamından piyasa mekanizmalarına bırakılması evsiz yoksulların artmasına neden olmuştur (Yılmaz, 2012: 272). Mevcut toplumsal değişimin ve kapitalist politikaların sonucunda aile kurumu olumsuz etkilenmiş, sorunlar artmış, güçsüzleşmiş ve ailede çözülmeler başlamıştır (Cılga, 2009: 10). Bu dönüşüm sonrasında aile bireyleri bireysel çözümlere yönelmişler, başarısız aile bireyleri marjinal yaşam biçimini geliştirmiş ve böylece evsizlik olgusu sosyal sorunlar arasında yerini almıştır.

Kabaca evi olmama ya da barınma intiyacını karşılamama durumu olarak tanımlanan evsizlik kavramının, birçok faktörden etkilendiği ve farklı kültürlerde farklı şekillerde ele alındığı görülmektedir (Özdemir, 2010: 79). Toplumun siyasal ve ekonomik durumundan doğrudan etkilenen evsizlik kavramı Avrupa ülkelerinde farklı anlamlar içerirken, Avrupa ülkelerinin tanımına göre nüfusunun büyük bir bölümü evsiz kabul edilebilecek Afrika ülkeleri için farklı anlamlar taşımaktadır. Dolayısıyla evsizliğe dair genel geçer bir kavramsal çıkarımda bulunmak oldukça güçtür. Bu çerçevede bir sosyal sorun olarak kabul edilen evsizlik sorununu tanımlama şekli, bu gruba sunulacak hizmetleri ve sosyal politikaları doğrudan etkileyeceği için diğer tüm sosyal sorunlarda olduğu gibi kavramsallaştırma sürecinin siyasi bir bakış açısından soyutlanamadığının da altını çizmek gerekmektedir.

Amerika'da battaniyeye sarılış şekilde sokaklarda yatan evsizler sıklıkla gözlemlenirken, Türkiye'de daha çok hastanelerin acil servisleri, otogarlar ya da tren 
istasyonları gibi kamusal alanlarda kalan evsizler dikkat çekmektedir (IIlhan ve Ergün, 2010: 80). Birleşik Devletler 'de farklı durumları kapsayacak şekilde iki farklı evsiz tanımı yapıldığı görülmektedir. Bu tanımların ilkinde barınma için kullanılmayan arabalar ve parklar gibi yerlerde uyuyanları evsiz olarak değerlendirilirken, diğerinde arkadaşlarının evinde ya da pansiyonlarda kalanları da evsiz olarak tanımlamaktadır (Helvie, 1999). Bu noktada sadece barınacak kendine ait bir evinin olmaması mı kişiyi evsiz yapmaktadır, yoksa barınacak bir evinin olmamasının yanında bu barınma ihtiyacını uygun olmayan yerlerde karşılayanlar da evsiz olarak ele alınmalı mıdır sorusu gündeme gelmektedir.

Birleşmiş Milletlere göre mutlak evsizlik, açık havada, araçlarda, terk edilmiş binalarda veya insan yerleşimi için uygun olmayan diğer yerlerde uyuyan, kalacak bir barınağı bulunmayan kişilerin durumunu açıklamaktadır (Hwang, 2001: 229). Amerika'da evsizlere yönelik yapılan bir çalışmada, evsizlerin yaşam koşullarını ifade eden genel bir açıklama getirilmiştir. Evsizlerin harap dökük baraka gibi mekânlarda yaşadıkları, sığınacak bir yere uzun süre sahip olmadıkları ve bu sığındıkları yerlerin terk edilmiş binalar ile otogar, otobüs durakları, arabalar, köprü altları gibi yerler olduğu, kısıtlı imkânlar ile ucuz pansiyonlarda kalabildikleri ve kamusal yardımlardan uzun süre yararlanamadıkları belirtilmektedir (Özdemir, 2010: 79; Akyıldız, 2017: 69-70).

Evsizlik, trajik sonuçlar doğurabilen, şehirlerde, kasabalarda ve kırsal alanlarda genel sağlığı olumsuz etkileyen (Plumb, 2000: 172), bireyin kendine güvenini, moralini ve sağlığını büyük ölçüde tahrip eden, yalnızca bireyi değil, aynı zamanda oluşumuna izin veren toplumu damgalayan bir sorundur (Crane ve diğ., 2006: 156). Evsizlikle birlikte bireyin yaşamında ortaya çıkabilecek sorunlar arasında sağlıksız beslenme, alkol, madde bağımlıı̆ı, şiddet, intihar, boşanma, yoksulluk, işsizlik, yabancılaşma, , sosyal dışlanma, depresyon ve evsizlik sayılabilir (Işıkhan, 2002: 35).

1990’ı yıllardan itibaren dünya genelinde yoksul nüfusun arttığı ve bu yoksul nüfusun içinde evsiz bireylerin ve ailelerin sayılarında da artış olduğu bildirilmektedir (Shinn ve diğ., 1998: 1651). Özellikle Birleşik Devletler 'de ve bazı Avrupa ülkelerinde geçici evsizler olarak da görülen evsiz ailelerin sayısının arttığı bildirilmektedir (Erbay, 2013). Evsiz insan sayısının, İskandinav ülkelerinde (Finlandiya ve Norveç vb.) binlerce, diğer Batılı endüstrileşmiş ülkelerde (İtalya ve Birleşik Krallık vb.) on binlerce, Doğu Avrupa, Rusya Federasyonu, Kafkaslar ve 
Orta Asya gibi diğer ülkelerde ise milyonlarca olduğu tahmin edilmektedir. (Erişim adresi, https://www.unece.org Erişim tarihi: 30.01.2018). Araştırmalara göre, 1980'lerden bu yana Amerika Birleşik Devletleri'ndeki (ABD) 1,5 milyon insanın sokaklarda yaşadığı, yaklaşık 3 milyon insanın yaşayabileceği bir evinin olmadığı ve 13.5 milyon insanın da hayatlarının bir döneminde evsiz kaldığı belirtilmektedir (Yıldırım ve Yıldırım 2014: 419). İngiltere'de 1980'lerin başından bu yana evsizlik, ülkenin büyük şehirlerinde ciddi bir sorunu oluşturmakta (Salit ve diğ., 1998: 1734), Kanada'da artan bir endişe konusu haline gelmektedir (Hwang, 2001: 229).

Dünyanın birçok ülkesinde yaşanan evsizlik olgusu ve sorunu, ülkemiz için de önemli bir sorun olmaya başlamıştır (İlhan ve Ergün, 2010: 80). Yirminci yüzyılın sonlarına doğru İstanbul başta olmak üzere büyük şehirlerde evsizlerin sayısındaki artış dikkat çekmektedir (Türkcan ve Türkcan, 1996: 8). Özellikle son yıllarda çeşitli sebeplerle komşu ülkelerden yoğun göç alması nedeniyle ülkemizdeki sisteme entegre olamayan göçmenlerin de evsizlik sorunu içinde önemli bir yer tutmaya başladıkları da görülmektedir.

Kişileri evsizliğe iten genel nedenler içinde; işgücü piyasası değişiklikleri, düşük maliyetli konut arzının yetersizliği ve gelir yardım programlarındaki kesintiler gibi yapısal faktörler yer almaktadır. Bireysel düzeydeki risk faktörleri olarak; yoksulluk, cinsiyet, etnik köken, yaş grubu, ruhsal bozukluk ve madde kötüye kullanım bozukluklarıdır (Herman ve diğ., 1997: 249). Yoksul insanların alt gruplarında yer alan kişiler evsiz kalmada yüksek risk altındadır. Bunlara travma sonrası stres sendromu bozukluğu olanlar, aile içi şiddet mağdurları, uyuşturucu ve alkol bağımlıları ve yeterli sosyal desteğe sahip olmayan kişiler eklenebilir (Plumb, 2000: 172). Amerika'da 1999 yılında ulusal düzeyde yapılan araştırmalarda, evsiz kalanların \% 40'ının ruhsal hastalığı olduğunu, \%85'inin bekâr olduğunu, \% 38'inin alkol ve \% 26'sının da madde bağımlısı olan kişilerden oluştuğu belirtilmektedir (Demir, 2017: 51).

Akyıldız (2017: 68), günümüzde evsizlere yönelik sosyal hukuk uygulamalarının bulunmadığını, bu konuda yapılan çalışmaların sivil toplum kuruluşları tarafından geçici yardımlar ekseninde, sınırlı sayıda uygulamalarla şekillendiği belirtiyor. Özdemir (2010: 87), ülkemizde evsizlik ile ilgili çalışmaların son derece sınırı olduğunu belirtmektedir. Bu açıdan değerlendirildiğinde çalışmanın; evsiz bireylere yönelik yapılacak sosyal politikaların üretilmesine katkı sağlayacağı ve çözüm önerilerinin geliştirilmesinde yerel yönetimlerin dikkatlerinin çekilmesinin sağlanması 
açısından önemli olduğu düşünülmektedir. Ayrıca, çalışmadan elde edilen bulguların, evsizlik olgusunun daha iyi anlaşılması, evsizlerin sorunlarının belirlenmesi, ihtiyaçlarının karşılanması konusunda alanda çalışan meslek elemanlarına doğrudan katkı sunacağı ve daha etkin çalışmalar yapılması konusunda olanak vereceği düşünülmektedir.

\section{YÖNTEM}

\section{Araştırmanın Amacı}

Araştırmanın amacı, evsiz bireylerin sosyo-demografik özelliklerini ve sokak yaşamına ilişkin deneyimlerini incelenmektir. Araştırmanın amacı doğrultusunda cevap aranan temel araştırma soruları şunlardır:

1. Evsiz bireylerin sosyo-demografik (cinsiyet, yaş, eğitim durumu, medeni durum, çocuk sahibi olma durumu, sokak yaşamı öncesinde kiminle birlikte yaşadığı) özellikleri nelerdir?

2. Evsiz bireylerin gelir ve çalışma durumuna ilişkin özellikleri (gelir durumu, sosyal yardım alma durumu ve çeşidi, daha önce çalışma durumu, sosyal güvence durumu) nelerdir?

3. Evsiz bireylerin fiziksel durumuna ilişkin (fiziksel hastalık durumu, madde kullanım durumu, kullandığı maddenin türü) özellikleri nelerdir?

4. Evsiz bireylerin sokak yaşam deneyimleri (sokakta yaşama süresi ve nedeni, görüşülen yakını olma durumu, sokak yaşamından kurtulma girişimi, sokakta kalınan mekân, kalınan mekânın mevsim şartlarına göre değişimi) nelerdir?

5. Evsiz bireylerin sokak yaşam deneyimine ilişkin düşünceleri (sokak yaşamını kendisi için uygun görme durumu, sokakta zamanını geçirme şekli, intiyaçlarını karşılama şekli, sokakta yaşamanın zorlukları ve riskleri, özlemini duydukları şey, sokaktan vazgeçmesine neden olabilecek sebep) nelerdir?

\section{Araştırmanın Modeli}

Bu çalışma tanımlayıcı ve kesitsel araştırma tipinde gerçekleştirildi ve Antalya Eğitim ve Araştırma Hastanesi Sosyal Hizmet Birimi'nde Ocak- Aralık 2018 tarihleri arasında yapıldı.

\section{Çalışma Grubu}

Çalışmanın evrenini, Antalya Eğitim ve Araştırma Hastanesi acil servisi, poliklinikleri ile yataklı klinikleri tarafından Sosyal Hizmet Birimi'ne havale edilen ya da şahsi 
olarak başvuru yapan evsiz bireyler oluşturdu. Bu kişilerden çalışmaya alınma ölçütlerine göre; okuryazar olan (anket formlarını anlayabilmesi ve tamamlayabilmesi amacıyla), en az 6 aydır sokaklarda yaşayan, yaşayacak bir evi olmayan ve çalışmaya katımaya gönüllü olan toplam 50 kişi çalışmanın örneklemini oluşturdu.

\section{Veri Toplama Araçları}

Verilerin toplanmasında, katılımcıların özelliklerini ile sokak yaşam deneyimlerini sorgulayan görüşme formu kullanıldı. Görüşme formu, katılımcıların sosyodemografik özelliklerine, gelir ve çalışma durumuna, fiziksel durumuna ve sokak yaşam deneyimlerine ilişkin bilgiler ile sokak yaşam deneyimine ilişkin düşüncelerini kapsayacak şekilde beş ana bölümden ve toplam 34 sorudan oluşturuldu.

\section{Veri Toplama Süreci}

Veriler araştırmacılar tarafından yapılan yüz yüze görüşme yöntemi ile toplandı. Veri toplama sırasında araştırmaya katılmaya gönüllü olan evsizlere onam formunu okumaları istenerek/okunarak araştırmanın amacını ve kapsamını anlamaları sağlandı.

\section{Verilerin Analizi}

Çalışmada elde edilen veriler Statistical Package for the Social Sciences (SPSS) 17 paket programı ile analiz edildi. Verilerin analizinde tanımlayıcı türde tasarlanan araştırma sorularına cevap verecek tanımlayıcı istatistikler kullanıldı.

\section{Araştırmanın Etik Boyutu}

Araştırma için Antalya Eğitim ve Araştırma Hastanesi Klinik Araştırmalar Etik Kurulu'ndan 08/02/2018 tarih ve 3/2 sayılı karar numarası ile "Etik Kurul Onayı" alındı. Çalışmaya katılım gönüllülük esasına göre sağlandı ve araştırmanın ismi, amacı, araştırmacının bilgileri ve etik kuralları içeren Gönüllü Katıım Formu katılımcılar tarafından okunarak imzalandı. Veri toplama ve uygulama sürecine onam alındıktan sonra başlandı.

\section{Araştırmanın Sınırlılıkları}

$\mathrm{Bu}$ araştırma; Araştırma Antalya Eğitim ve Araştırma Hastanesi Sosyal Hizmet Birimi'ne başvuran ve havale edilen, örneklem seçim kriterlerine uyan ve araştırmaya katılmayı kabul eden evsizler ile sınırlıdır.

\section{BULGULAR}


Çalışmada elde edilen bulgular katılımcıların sosyo-demografik özelliklerine, gelir ve çalışma durumuna, fiziksel durumuna ve sokak yaşam deneyimlerine ilişkin bilgiler ile sokak yaşam deneyimine ilişkin düşüncelerine ilişkin bulgular olmak üzere beş bölümde ele alındı.

Katılımcıların sosyo-demografik özellikleri çerçevesinde cinsiyet, yaş, eğitim durumu, medeni durumu, çocuk sayısı ve sokak yaşamı öncesinde kiminle birlikte yaşadığı değişkenlerine yer verildi.

Tablo 1. Evsiz bireylerin sosyo-demografik özellikleri

\begin{tabular}{|c|c|c|c|}
\hline & & $\mathbf{n}$ & $\%$ \\
\hline \multirow[t]{2}{*}{ Cinsiyet } & Kadın & 2 & 4,0 \\
\hline & Erkek & 48 & 96,0 \\
\hline \multirow[t]{4}{*}{ Yaş } & $19-30$ yaş arası & 10 & 20,0 \\
\hline & $31-45$ yaş arası & 12 & 24,0 \\
\hline & $46-59$ yaş arası & 23 & 46,0 \\
\hline & 60 yaş üstü & 5 & 10,0 \\
\hline \multirow[t]{4}{*}{ Eğitim Durumu } & Okuryazar & 5 & 10,0 \\
\hline & İlkokul mezunu & 21 & 42,0 \\
\hline & Ortaokul mezunu & 9 & 18,0 \\
\hline & Lise mezunu & 15 & 30,0 \\
\hline \multirow[t]{3}{*}{ Medeni Durumu } & Bekâr & 21 & 42,0 \\
\hline & Evli & 3 & 6,0 \\
\hline & Boşanmış & 26 & 52,0 \\
\hline \multirow{2}{*}{$\begin{array}{l}\text { Çocuk Sahibi Olma } \\
\text { Durumu }\end{array}$} & Evet & 28 & 56,0 \\
\hline & Hayır & 22 & 44,0 \\
\hline \multirow{5}{*}{$\begin{array}{l}\text { Sokakta Yaşamadan } \\
\text { Önce Kiminle Birlikte } \\
\text { Yaşadığı }\end{array}$} & Anne ve/veya baba ile & 17 & 34,0 \\
\hline & Eş ile & 15 & 30,0 \\
\hline & Kardeşiyle & 1 & 2,0 \\
\hline & Arkadaşıyla & 3 & 6,0 \\
\hline & Tek başına & 14 & 22,0 \\
\hline
\end{tabular}

Tablo 1'de yer alan çalışmaya katılan evsiz bireylerin demografik özelliklerine bakıldığında; \%96'sının erkek, \%4'ünün kadın, \%46'sının 46-59 yaş aralığında, \%24'ünün 31-45 yaş aralığında, \%20'sinin 19-30 yaş aralığında ve \%10'unun 60 yaş üzerinde olduğu anlaşılmaktadır. Eğitim durumları incelendiğinde ise, \%42'sinin ilkokul, \%30'unun lise ve \%18'inin ortaokul mezunu olduğu görülmektedir. Katılımcıların \%52'si boşanmış, \%42'si bekâr ve \%6'sı evlidir ve \%56'sının çocuğu vardır. Katılımcıların sokakta yaşamadan önce, \%34'ünün anne ve/veya babası ile \%30'unun eşi ile birlikte ve \%26'sının tek başına yaşadığı belirlendi. 
Evsiz bireylerin gelir ve çalışma durumuna ilişkin bilgilere gelir durumu, sosyal yardım alma durumu, yardımın alındığı kurum, daha önce çalışma durumu, sosyal güvence durumu değişkenleri çerçevesinde yer verildi.

Tablo 2. Evsiz bireylerin gelir ve çalışma durumuna ilişkin bilgiler

\begin{tabular}{|c|c|c|c|}
\hline & & $\mathbf{n}$ & $\%$ \\
\hline \multirow[t]{4}{*}{ Gelir Durumu } & Emekli maaşı & 3 & 6,0 \\
\hline & 2022 engelli aylığı & 4 & 8,0 \\
\hline & Geliri olmayan & 42 & 84,0 \\
\hline & Yetim aylığı & 1 & 2,0 \\
\hline \multirow{2}{*}{$\begin{array}{l}\text { Sosyal Yardım Alma } \\
\text { Durumu }\end{array}$} & Evet & 19 & 38,0 \\
\hline & Hayır & 31 & 62,0 \\
\hline \multirow{4}{*}{$\begin{array}{l}\text { Yardımın } \\
\text { Kurum }\end{array}$} & Hastane sosyal hizmet birimi & 2 & 10,5 \\
\hline & Belediye sosyal hizmet birimi & 3 & 15,8 \\
\hline & ASPIM & 2 & 10,5 \\
\hline & Kaymakamlık SYDV & 12 & 63,2 \\
\hline \multirow{2}{*}{$\begin{array}{l}\text { Daha Önce Çalışma } \\
\text { Durumu }\end{array}$} & Evet çalıştım & 47 & 94,0 \\
\hline & Hayır çalışmadım & 3 & 6,0 \\
\hline \multirow{5}{*}{$\begin{array}{l}\text { Sosyal } \\
\text { Durumu }\end{array}$} & Sosyal güvencesi olmayan & 28 & 56,0 \\
\hline & Emekli sandığı & 1 & 2,0 \\
\hline & SSK & 5 & 10,0 \\
\hline & BAĞ-KUR & 1 & 2,0 \\
\hline & Genel Sağlık Sigortası & 15 & 30,0 \\
\hline
\end{tabular}

Tablo 2'de yer verilen evsiz bireylerin gelir ve çalışma durumuna ilişkin bilgiler incelendiğinde \%84 gibi büyük çoğunluğunun gelirinin olmadığı, \%8'inin 2022 Sayılı Kanun kapsamında engelli aylığı ve \%6'sının emekli maaşı aldığı anlaşılmaktadır. Katılımcılardan \%38'inin (ayni ya da nakdi yardım kapsamında) kamu kurumundan yardım aldığı görülmektedir. Yardım aldığını belirtenlerin yarısından fazlası (\%63,2'si) Antalya Valiliği Sosyal Yardımlaşma ve Dayanışma Vakfı'ndan (SYDV) yardımı aldığını belirtmiştir. Ayrıca katıımcıların yarısından fazlasının (\%56) sosyal güvencesinin olmadığı belirlendi.

Katılımcıların \%94'ü sokakta yaşamadan önce çalıştıklarını belirtmişlerdir. Bu dönemde çalıştıkları işlerin ise çiftçi, otelde kat temizliği, hamal, kasap, şoför, inşaat işçisi, güvenlik görevlisi, serbest meslek, otobüs muavini, saat tamircisi, garson, sera işçisi, aşçı, kunduracı, bekçi, bulaşıkçı, mobilya ustası, tır şoförü, çoban, tekstil işçisi, çaycı olduğu anlaşılmaktadır. 
Tablo 3. Evsiz bireylerin fiziksel ve ruhsal sağlık durumuna ilişkin bilgiler

\begin{tabular}{llll}
\hline \multirow{2}{*}{ Kronik Hastalığı Olma Durumu } & & $\mathbf{n}$ & $\%$ \\
& Yok & 24 & 48,0 \\
\cline { 2 - 4 } & Var & 26 & 52,0 \\
\hline Madde Kullanım Durumu & Evet & 29 & 58,0 \\
\cline { 2 - 4 } & Hayır & 21 & 42,0 \\
\hline Kullanılan Maddenin Türü & Sigara & 18 & 62,1 \\
\cline { 2 - 4 } & Uyuşturucu & 4 & 13,8 \\
\cline { 2 - 4 } & Alkol & 7 & 24,1 \\
\hline
\end{tabular}

Evsiz bireylerin fiziksel ve ruhsal sağlık durumuna ilişkin bilgilerin bulunduğu Tablo 3'e bakıldığında katılımcıların \%52'sinin kronik bir hastalığı olduğu görülmektedir. Buna göre; 7 kişide KOAH (Kronik Obstrüktif akciğer hastalığı), 4 kişide mantar rahatsızlığı, 2 kişide ruhsal hastalık, 2 kişide siroz hastalığı, 3 kişide kanser teşhisinin konduğunu (lösemi, akciğer ve kolon kanseri), 2 kişide böbrek rahatsızlığı, 1 kişide verem hastalığı ve 1 kişide epilepsi hastalığının olduğunu belirlendi.

Evsiz bireyler arasında madde kullandığını belirtenlerin oranı \%58'dir. Madde kullananların \%62,1'i sigara, \%24,1'i alkol ve \%13,8'i uyuşturucu kullanmaktadır. 
Tablo 4. Evsiz bireylerin sokak yaşam deneyimlerine ilişkin bilgiler

\begin{tabular}{|c|c|c|c|}
\hline & & $\mathbf{n}$ & $\%$ \\
\hline \multirow[t]{4}{*}{ Sokakta Yaşanılan Süre } & 1 yıldan az & 14 & 28,0 \\
\hline & 1-2 yıl arası & 7 & 14,0 \\
\hline & 2-4 yıl arası & 9 & 18,0 \\
\hline & 5 yıl ve daha fazla & 20 & 40,0 \\
\hline \multirow[t]{5}{*}{ Sokakta Yaşama Nedeni } & Kendi isteği & 8 & 16,0 \\
\hline & Yaşayan yakını olmaması nedeniyle & 1 & 2,0 \\
\hline & Ailenin sahip çıkmaması & 15 & 30,0 \\
\hline & Ruhsal hastalık nedeniyle & 4 & 8,0 \\
\hline & Ekonomik nedenler & 22 & 44,0 \\
\hline \multirow{2}{*}{$\begin{array}{l}\text { Görüşülen Yakını Olma } \\
\text { Durumu }\end{array}$} & Yok & 41 & 83,7 \\
\hline & Var & 8 & 16,3 \\
\hline \multirow{8}{*}{$\begin{array}{l}\text { Sokaktan Kurtulmak için } \\
\text { Girişimde } \\
\text { Durumu } \\
\text { Sokakta Mekan } \\
\text { Kalınan Ylarak } \\
\text { Kalın }\end{array}$} & Evet & 36 & 73,5 \\
\hline & Hayır & 13 & 26,5 \\
\hline & Hastaneler & 23 & 46,0 \\
\hline & Terminal & 1 & 2,0 \\
\hline & Parklar & 5 & 10,0 \\
\hline & $\begin{array}{l}\text { Kullanılmayan gecekondu ve } \\
\text { inşaatlar }\end{array}$ & 4 & 8,0 \\
\hline & Kapalı spor salonu & 11 & 22,0 \\
\hline & Diğer & 6 & 12,0 \\
\hline \multirow{2}{*}{$\begin{array}{l}\text { Mevsim şartlarına göre } \\
\text { mekan değişim durumu }\end{array}$} & Evet & 30 & 61,2 \\
\hline & Hayır & 19 & 38,8 \\
\hline \multirow{2}{*}{$\begin{array}{l}\text { Sokakları kendisi için } \\
\text { uygun görme durumu }\end{array}$} & Evet & 3 & 6,0 \\
\hline & Hayır & 47 & 94,0 \\
\hline
\end{tabular}

Evsizlerin sokaktaki yaşamlarına yönelik alınan bilgilerin bulunduğu Tablo 4'e bakıldığında; katılımcıların \%40'ının 5 yıldan fazla, \%28'inin 1 yıldan az, \%18'inin 24 yıl arası ve \%14'ünün 1-2 yıl arası sokakta yaşadığı belirlendi. Sokakta yaşamaya neden olan faktörler incelendiğinde, katılımcıların \%44'ünün ekonomik nedenlerle, \%30'unun ailenin kendisine sahip çıkmaması, \%16'sının kendi isteğiyle, \%8'inin ruhsal hastalık nedeniyle sokakta yaşadığı belirlendi. Görüşülen herhangi bir yakını olma durumuna ise katıımcıların büyük bir çoğunluğu $(\% 86,7)$ görüştüğü bir yakını olmadığını belirtmiştir. Sokaktan kurtulmak için herhangi bir girişimde bulunup bulunmama durumu incelendiğinde ise $\% 73,5^{\prime}$ inin sokakta yaşamaktan kurtulmaktan için girişimde bulunduğu anlaşılmaktadır. Bu girişimlerin işe girme, sokakta yaşayan arkadaşlarıyla eve taşınma, kısa bir süre akrabaların yanına sığınma vb. olduğu görüldü. 
Sokakta mekân olarak seçilen yerler bakımından katılımcıların \%46'sının hastanelerde, \%22'sinin kapalı spor salonunda ve \%10'unun parklarda, \%8'inin kullanılmayan gecekondu ya da inşaatlarda kaldıklarını belirlendi. Ayrıca katıımcıların yarısından fazlasının $(\% 61,2)$ mevsim şartlarına göre kaldıkları mekânı değiştirdikleri, yaz aylarında çoğunlukla parklarda kaldıkları, kış aylarında ise zorunlu olarak kapalı alanları tercih ettikleri anlaşılmaktadır.

Katılımcıların sokak yaşam deneyimine ilişkin görüşleri incelendiğinde, katılımcıların tamamına yakınının (\%96) sokakların kendisi için uygun olmadığını düşündüğü anlaşılmaktadır. Katılımcıların sokakta zamanını geçirme şekline bakıldığında ise, katııımcılar tarafından büyük çoğunluğunun sürekli yürüyüş yaptığı, bazen kilometrelerce gezdiği, parklarda oturduğu ya da hastane çevresinde zaman geçirdiği, soğuk havada ise hastane acil servisinin girişinde vakit geçirdiği, bir bölümünün ise gündüz çöplerden şişe, kâğıt ve hurda topladığı bilgisine ulaşıldı.

Katılımcıların intiyaçlarını karşılama şekillerine bakıldığında; insanların kıyafet gibi benzeri yardımlarda bulundukları, belediye ve gönülülerin ortak katkısı ile sabah çorba ve akşam yemek ikramının yapıldığı, banyo yapmak gibi önemli intiyaçlarını camide ya da yaz aylarında fıskiyeli havuzda karşıladıkları ifade edildi. Katılımcılardan bir bölümü hurda, cam şişe, kâğıt topladıklarını ya da gündelik iş bulduğunda para kazanıp pansiyonda kaldığı ve banyo yapabildiğini belirtmiştir. Bir katılımcı ise çöpten kıyafet bulduğunda üstünü değiştirebildiğini ifade etmiştir.

Sokakta yaşamanın zorlukları konusunda, katıımcılar tarafından kışın soğuk havanın dayanılmayacak düzeyde olduğu ve uykusuzluk sorunu yaşadıkları, madde bağımlıların kendilerine şiddet uyguladığı, hırsızlığa maruz kaldıkları, can güvenliklerinin olmadığı ve çoğunlukla ölüm korkusu yaşadıkları, insanlar tarafından hor görüldükleri, intiyaçlarını karşılayamadıklarından genelde açlık yaşadıkları belirtildi.

Katılımcılar sokaktaki yaşadıkları risklere bakıldığında; soğuk hava nedeniyle solunum yollarından sürekli hasta olduklarını, yıkanamamaları nedeniyle mantar enfeksiyonları ile bulaşıcı hastalıklara maruz kaldıklarını belirtmişlerdir.

Katılımcılar tarafından hayatlarında en çok özlemini duydukları arasında; aile sevgisi ve ortamı (\%30), sıcak bir yatak ve huzurlu uyku uyuma (\%14), çalışıp para kazanma (\%8), çocukluk özlemi (\%4), topluma faydalı olma (\%2), insancıl davranışları (\%2) yer aldı. Katılımcılardan 20 kişi özlemini duyduğu hiçbir şey olmadığını ifade etmiştir. 
Kendilerine hangi imkân sunulursa sokakta yaşamaktan vazgeçersiniz sorusuna; çoğunluğu iş (\%48), kurum bakımında kalmak (\%10), kalacak küçük bir ev ya da oda (\%6), ekonomik yardım (\%6) emeklilik (\%2) olarak yanıtladı. Katılımcılardan üç kişi hangi imkân sunulursa sunulsun sokaktan vazgeçmeyeceklerini ifade etmişlerdir.

\section{TARTIŞMA}

Bu çalışma, evsiz bireylerin sosyo-demografik özelliklerini ve sokak yaşamına ilişkin deneyimlerini inceleme amacı ile tanımlayıcı ve kesitsel araştırma tipinde gerçekleştirildi. Çalışmada görüşme yapılan evsiz bireylerin tamamına yakınının (\%96) erkeklerden oluştuğu belirlendi. Genel olarak bakıldığında dünya genelinde evsizliği erkeklerin kadınlara oranla daha çok deneyimledikleri görülmektedir. ABD'de 2009-2018 yılları arasında evsiz her on bireyin altısını erkekler oluşturmaktadır (U.S. Department of Housing and Urban Development, 2018). 2018 yılında gerçekleştirilen bir araştırmada evsizliği deneyimleyenlerin \% 60,1'inin erkeklerden, \% 6'sının ise kadınlardan oluştuğu sonucuna ulaşılmıştır (U.S. Conference of Mayors, 2018). Ülkemizde durum genel olarak evsizlerin çoğunlukla erkeklerden oluştuğunu göstermektedir. Kılıç ve diğ. (2015: 71) tarafından acil servislerdeki evsiz hastaların sosyo-demografik özelliklerinin ve klinik durumlarının belirlenmesi amacıyla gerçekleştirilen bir çalışmada katılımcıların \% 89,7'sinin erkek olduğu ve yaş ortalamalarının ise 63 olduğu belirtilmiştir. Evsiz bireylerin çoğunlukla erkeklerden oluşması toplumsal cinsiyet boyutunda kamusal alanın kadından daha ziyade erkekle özdeşleştirilmesi ile açıklanabilir. Kadının ev, çocuklar ve aile ile ifade edilen özel alanda tanımlanması bu alanın tamamen dışında olma durumu olarak kavramsallaştırılan evsizlik deneyimi ile zıt bir özellik sergilemektedir. Ayrıca sokakların tehlikelerinden kadınların erkeklere oranla daha çok etkilenmesi de evsizler içinde kadın sayılarının az olması ile ilişkilendirilebilir. Yapılan araştırmalar evsiz kadınların erkeklere oranla daha çok duygusal ve cinsel istismar yaşadığını göstermektedir (Christensen ve diğ.. 2005: 615; Roos ve diğ., 2013: 279). Her ne kadar sayısal olarak evsiz erkekler çoğunlukta olsa da kadınların evsiz olma nedenlerinin toplumsal cinsiyetle ilişkili nedenlerle ilgili olması, kadın olmanın dezavantajlı konumunun evsizlik fenomeninde de onaylanması olarak değerlendirilebilir (Baptista 2010: 169; Doherty 2001: 9-12; Quilgar and Pleace 2010: 97; Young 2010: 2). 
Çalışmada elde edilen bir diğer sonuç, katıımcıların yarısına yakınının (\%46) 46-59 yaş aralığında olduğu, çok küçük bir bölümünün ise 60 yaş üzerinde olduğudur. Literatürde de evsizlerin çoğunlukla 24 yaş üstü bireylerden oluştuğu görülmektedir (US Department of Housing and Urban Development, 2018). 30 ila 39 yaş grubunda olmak evsizlik açısından risk grubunda olmak olarak değerlendirilmektedir (Susser ve diğ., 1993; 548). Ancak çalışmada yabancı literatürde sıklıkla rastlanan adölesan ya da çocuk evsizlere rastlanmadığı görülmektedir. Amerika'da 2003 yılında evsiz nüfusun \% 39'unu 18 yaş altı çocukların oluşturduğu, bu grubun \% 42'sinin ise beş yaş altı çocuklardan oluştuğu bildirilmektedir (National Law Center on Homelessness and Poverty, 2004). Bu durum özellikle evsiz aileler fenomeni ile açıklanabilir. Ülkemizde evsiz ailelere sıklıkla rastlanmaması ve sokakta yaşayan çocuklarla ilgili alınan tedbir kararları 18 yaş altı grupta evsizlik olgusunun düşük olmasının sebebi olarak ele alınabilir. Yetişkinler ve yaşlı evsizlerin ise evsizlik sarmalından kurtulmak için gençlere oranla daha az sosyal kaynağa sahip oldukları görülmektedir (Hecht ve Coyle, 2001: 72). Ayrıca ülkemizde kavramsal olarak 18 yaş altında sokakta yaşayan çocukların evsiz nüfus içinde değerlendirilmekten ziyade, çocuk olmaktan kaynaklanan özellikli durumları nedeniyle "sokak çocukları" ya da "sokakta yaşayan çocuklar" kavramı ile açıklanmaktadır.

Çalışma sonucunda evsizlerin \%42'sinin ilkokul mezunu olduğu görüldü. Düşük eğitim seviyesine sahip olmak genel olarak sosyal risklere açık olmayı beraberinde getiren bir özellik olarak değerlendirilmektedir. Evsizlik bu riskler içinde bireyin hayatına doğrudan ve yıkıcı bir şekilde etki etmesi açısından önemli bir yere sahiptir. Eğitim sürecinin devam ettiği yaş grubu açısından bakıldığında ise evsiz gençlerin büyük bölümünün okulu bıraktıkları dikkat çekmektedir (Hagan ve McCarthy, 1998: 264). Dolayısıyla eğitim ve evsizlik arasındaki ilişki analiz edildiğinde ikili bir yapının varlığından söz edilebilir. Bir yandan düşük eğitim düzeyinin evsizlik açısından bir risk faktörü olarak ele alındığı görülürken, diğer yandan evsizliği deneyimleyen gençlerin eğitim hayatına devam etme imkânların da çok yüksek oranda olmadığı anlaşılmaktadır. Bu sarmal yapı evsizliğin devam etmesi ve kronik hale gelmesi açısından önemli bir unsur olarak değerlendirilebilir.

Katılımcıların yarısı (\%52) boşanmış, yarısına yakını (\%42) bekârdır ve sokakta yaşamaya başlamadan önce çoğunluğu ya anne ve/veya baba ile ya da eşi ile birlikte yaşamıştır. Çalışmanın bulgularına benzer nitelikte 2018 yııında gerçekleştirilen bir araştırmada Amerika'da evsiz nüfusun \% 51'inin bekâr 
erkeklerden oluştuğu görülmüştür (U.S. Conference of Mayors, 2005). Ailesinden uzakta yaşayan evsizler için aile yaşamına ilişkin büyük bir özlem olduğu da yine katılımcılarla yapılan görüşmelerde hayatlarında en çok özlemini duydukları şeyin ne olduğu sorusuna verdikleri cevaplardan anlaşılmaktadır. En çok özlemini duydukları şeylerin aile sevgisi ve ortamı, çocukluk özlemi, sıcak bir yatak, huzurlu uyku uyuma gibi ev ve aileye ilişkin kavramların yer aldığı dikkat çekmiştir. Her ne kadar aile ve ev özleminden söz etseler de katılımcıların büyük bir çoğunluğu $(\% 86,7)$ görüştüğü bir yakını olmadığını belirtmiştir.

Katılımcıların gelir durumlarına bakıldığında, \%84 gibi büyük çoğunluğunun gelirinin olmadığı, \%56'sının herhangi bir sosyal güvencesinin bulunmadığı belirlendi. Ayrıca, katılımcılardan \%38'inin kamuya ait bir kurumdan sosyal yardım aldığı görüldü. Levitt ve diğ. (2009: 980-981) tarafından Manhattan'da kronik ve kronik olmayan evsizlerin özelliklerini karşılaştırmak amacıyla gerçekleştirilen araştırmada tüm katıımcıların \% 47'sinin düşük oranda sağlık sigortasına sahip olduğu ve \% 26 'sının hiçbir gelire sahip olmadığı, \% 11'inin ise sosyal yardım aldığı sonucuna ulaşılmış, bu oranların kronik evsizlerde kronik olmayan evsizlere kıyasla daha yüksek olduğu vurgulanmıştır. Evsizlik genel olarak yoksullukla, barınacak düzenli bir yaşantıya sahip olacak düzenli bir gelire sahip olmama durumu ile açıklanmaktadır. Dolayısıyla sokakta yaşamak düzenli bir gelirden ve sosyal güvenceden mahrum olmayı da beraberinde getirmektedir.

Katılımcıların tamamına yakını (\%94) sokakta yaşamadan önce çalıştıklarını belirtmektedir. Çeşitli sektörlerde çalıştıkları anlaşılan evsizlerin yaptıkları işlerin ortak noktası hizmet sektöründe ve düşük ekonomik getirisi olan işlerde çalışmaları olarak değerlendirildi. Bu noktada bireyin çalıştığı işten elde ettiği gelirin düzenli bir yaşam sürmeye yetmediği anlaşılmaktadır. Bu veri, katıımcıları evsizliğe iten nedenlerle ilişkili olarak ele alındığında, evsizlerin yarıya yakın bir bölümünün (\%44) ekonomik nedenleri işaret ettiği dikkat çekmektedir. Tamamına yakın bir bölümünün ücretli bir işte çalışırken evsizliği deneyimlemesi, aldıkları ücretin rutin devam eden yaşamlarındaki intiyaçlarını karşılamaya yetmediği şeklinde yorumlanabilir.

Sağlıksız yaşam koşulları nedeniyle evsizlerin \%52'sinin kronik bir hastalığı olduğu belirlendi. Tanı konulan hastalıklar arasında; KOAH (Kronik Obstrüktif akciğer hastalığı), mantar rahatsızlığı, ruhsal hastalık, siroz hastalığı, kanser (lösemi, akciğer ve kolon kanseri), böbrek rahatsızlığı, verem ve epilepsi hastalığının olduğunu belirlendi. Evsizlik bireyi fiziksel, ruhsal ve duygusal açıdan doğrudan 
etkileyen bir süreçtir. Evsizler öncelikle sokakta yaşamaktan kaynaklı olarak yüksek oranda fiziksel hastalık ve ölüm riskiyle karşı karşıya kalmaktadır (Salit ve diğ., 1998: 1734; Hwang 2001: 230). Karşılaştıkları hastalıklar çoğunlukla kronik obstrüktif akciğer hastalığı, nöbetler, artrit ve diğer kas-iskelet sistemi bozuklukları, tüberküloz, deri ve ayak sorunları özellikle selülit, impetigo, venöz staz hastalığı, uyuz ve vücut biti gibi cilt hastalıkları görülmektedir (Hwang, 2001: 230-231). Bir evin koruyuculuğundan ve konforundan mahrum olan bu grupta ruhsal sorunlara da sıklıkla rastlanmakta; psikotik bozukluklar genel topluma kıyasla evsizlerde daha fazla görülmektedir (Binbay ve diğ., 2010: 11).

Evsiz bireyler arasında madde kullandığını belirtenlerin oranı \%58'dir. Madde kullananların \%62,1'i sigara, \%24,1'i alkol ve \%13,8'i uyuşturucu kullanmaktadır. Ayrıca, katılımcılar sokakta yaşama sürecinde karşılaştıkları riskleri ise fiziksel hastalıklardan korunamama (soğuk hava nedeniyle oluşabilecek solunum yolu hastalıkları, hijyen sorunu nedeniyle oluşabilecek mantar enfeksiyonları ya da bulaşıcı hastalık riski gibi) çerçevesinde ele almışlardır. Genel olarak evsizlerin karşılaştıkları riskler yaş grupları açısından değerlendirildiğinde ise evsiz gençlerin kendi evlerinde yaşayan akranlarına göre, sağlıklarıyla ilgili daha büyük risk altında oldukları dikkat çekmektedir. Bu riskler arasında immün yetmezlik (HIV) ve diğer cinsel yolla bulaşan bulaşıcı hastalıklar; madde bağımlılığı; depresyon ve intihar girişimleri; fuhuş; ve travma yer almaktadır (Ringwalt ve diğ., 1998: 1325). Işıkhan (1995) tarafından Ankara'da 58 evsiz birey ile gerçekleştirilen çalışmada evsiz yetişkinlerin \%33'ünün uyuşturucu, sigara, alkol bağımlılığı, evsiz çocukların ise \%92'sinin tiner bağımlısı olduğu sonucuna ulaşımıştır. Ayrıca sokaklarda yaşamanın güvenlik açısından dezavantajlı durumuna paralel olarak evsiz erkekler arasında kasıtsız yaralanmaların öncelikli morbidite ve mortalite nedeni olduğu da görülmektedir (Hwang, 2001: 229).

Çalışmada elde edilen en önemli bulgulardan biri de sokakta yaşamaya neden olan faktörlerdir. Katılımcılardan \%44'ü ekonomik nedenlerle, \%30'u ailenin kendisine sahip çıkmaması, \%16'sı kendi isteğiyle ve \%8'i ruhsal bozukluk nedeniyle sokakta yaşadıklarını belirtmişlerdir. Yoksulluğun en görünür hali olarak değerlendirilen evsizlik olgusunun ekonomik sebeplerle ortaya çıkması beklenen bir sonuç olarak yorumlanabilir. Yoksulluk bu konuda en önemli risk faktörlerinden biri olarak değerlendirilmektedir (Herman ve diğ., 1997: 249). Ardından aile problemleri evsizliğe neden olan ikinci büyük neden olarak görülmektedir. Özellikle genç yaş grubunda ailevi sebeplerle sokakta yaşamaya başlamanın yaygın olduğu 
görülmektedir. Jacub ve diğ. (2011: 1891) tarafından Prag'da genç evsizlerle gerçekleştirilen bir çalışmada sokakta yaşama nedenlerinin en yüksek oranda ailevi sebepler olduğu görülmüştür.

Evsizlerin sokaktaki yaşamlarına yönelik alınan bilgilere bakıldığında; katılımcıların \%40'ı 5 yıldan fazla süredir sokakta yaşadığı belirlendi. Çok yüksek oranda 5 yıl ve üzeri sürelerde sokakta yaşama deneyimi olan evsizlerin varlığı, evsizliğin kronik hale geldiğine işaret etmektedir. Özellikle kısa süreli sokakta yaşama deneyimlerinde bu süreç bir geçiş aşaması olabilmekte, sokakta yaşayan bireyler sokakta yaşamalarına neden olan sorunlarla baş edebildiklerinde bu süreci sonlandırabilmektedirler.

Katılımcıların yarısından fazlasının $(\% 61,2)$ mevsim şartlarına göre kaldıkları mekânı değiştirdikleri, yaz aylarında çoğunlukla parklarda kaldıkları, kış aylarında ise zorunlu olarak kapalı alanları tercih ettikleri belirlendi. Literatürde de benzer şekilde kronik evsizlerin çoğunlukla açık alanlarda kaldıkları, ardından metro ya da geçici barınma merkezlerinde geceledikleri, ancak mevsim şartları çerçevesinde bu geceyi geçirecek yer bulma konusundaki stratejilerini değiştirdikleri görülmektedir (Levitt, 2009: 980-981).

Katılımcılar sokakta yaşamanın zorlukları olarak kış aylarında soğuk havayla mücadele, açlık, uyku problemleri, şiddete ve hırsızlığa maruz kalma, sosyal dışlanma ve aşağılanma, can güvenliği ve ölüm korkusu gibi zorluklar yaşadıklarını belirtmişlerdir. Şiddet, evsiz insanların sağlığı için sürekli bir tehdittir. Toronto'da yapılan bir çalışmada, evsizlerin \% 40'ının saldırıya maruz kaldığı, evsiz kadınların \% 21'inin tecavüze uğradığı, evsiz erkeklerin genel nüfustaki muadillerinden yaklaşık 9 kat daha fazla katledildikleri belirlenmiştir (Hwang, 2001: 231).

Katılımcıların tamamına yakını (\%96) sokakların kendileri için uygun olmadığı görüşüne sahip olduklarını ve büyük bir çoğunluğu $(\% 73,5)$ sokaktan kurtulmak için işe girme, sokakta yaşayan arkadaşlarıyla birlikte eve taşınma, kısa süreli akrabalarının yanına sığınma gibi girişimlerde bulunduklarını belirtmişlerdir. Ücretli bir işe sahip olma ya da emeklilik hakkına erişme, kurum bakımı gibi durumlarda sokakta yaşamaktan vazgeçeceklerini belirten katılımcılar arasında çok küçük bir grup (\%4) hangi imkân sunulursa sunulsun sokakta yaşamaktan vazgeçmeyeceklerini belirtmişlerdir. 


\section{SONUÇ VE ÖNERILER}

Çalışmanın temel sonuçları; çalışmaya katılan evsizlerin çoğunlukla 45-59 yaş arası, bekâr, ilkokul mezunu, erkeklerden oluştuğu, sokak yaşamı öncesinde çoğunlukla aileleriyle birlikte yaşadıkları, yine aynı dönemde ücretli bir işte çalıştıkları, dolayısıyla toplumsal yaşamın içinde oldukları anlaşıldı. Çoğunlukla ekonomik nedenlerle sokakta yaşadıkları, düzenli bir gelirlerinin ve sosyal güvencelerinin olmadığı; intiyaçlarını sosyal yardımlarla ve gönüllüler çerçevesinde karşıladıkları, çoğunluğunun 5 yıl ve daha fazla süredir sokakta yaşaması nedeniyle kronik evsiz oldukları, fiziksel ve ruhsal sağlık problemleri yaşadıkları ve sokakta yaşamlarını sürdürmekle ilgili çeşitli stratejiler geliştirdikleri görüldü. Genel olarak sokakta yaşamanın risklerinin farkında oldukları ve uygun koşullar sağlandığında sokakta yaşamaktan vazgeçebilecekleri anlaşıldı.

Elde edilen bu sonuçlar çerçevesinde koruyucu ve önleyici çalışmalar kapsamında öncelikle risk gruplarına yönelik olarak çalışmalar yapılması, düzenli bir işte çalışan ve sosyal işlevselliğini koruyan düşük gelir seviyesine sahip bireylerin desteklenmelerini sağlayacak politikaların oluşturulması önerilebilir. Bu noktada işsizlikle mücadele kapsamında yapılan çalışmaların genişletilmesi, sistemin dışına çıkan bireylerin ya da ailelerin daha uzun süreli ekonomik ve psikososyal açıdan desteklenmesi önemli bir önleyici tedbir olarak görülmektedir. Özellikle düşük gelir seviyesine sahip ve psikososyal açıdan riskli ailelerin sürekli olarak desteklenmesini sağlayacak bir meslek profesyoneli ile çalışmasını sağlamanın da önemli bir etkisinin olacağı düşünülmektedir.

Evsizlerin yaşadığı en önemli sorunlardan biri olan özellikle kış aylarında kapalı mekânlarda barınma olanaklarının arttırılması olduğundan, birincil olarak Belediyeler bünyesinde barınma, beslenme, tedavi ve sosyal yardım gibi hizmetlerin düzenli ve ulaşılabilir hale getirilmesi evsizlerin yaşadığı fiziksel ve ruhsal sağlık sorunlarının engellenmesinde önemli rol oynayacağı gibi istismara ve şiddete maruz kalma intimalini de azaltacaktır.

\section{KAYNAKÇA}

Akyıldız, Y. (2017). Dünyada ve Türkiye'de evsizlik sorunu ve çeşitli uygulamalar. LAÜ Sosyal Bilimler Dergisi, 8 (1), 67-91.

Baptista, I. (2010). Women and Homelessness. In Busch-Geertsema, V., O'Sullivan, E., Pleace, N. and Quilgars, D. (Eds.) (2010). Reflections on Homelessness Research 
in Europe, 1990-2010: A Festschrift to Honour Bill Edgar and Joe Doherty (pp. 163186), Brussels: FEANTSA.

Binbay, T., Ulaş, H., Elbi, H., Alptekin, K. (2010). Türkiye'de psikoz epidemiyolojisi: Yaygınlık tahminleri ve başvuru oranları üzerine sistematik bir gözden geçirme. Türk Psikiyatri Dergisi, 22(1), 40-52.

Christensen, R. C., Hodgkins, C. C., Garces, L., Estlund, K. L., Miller, M. D., Touchton, R. (2005). Homeless, mentally ill and addicted: The need for abuse and trauma services. Journal of Health Care for The Poor and Underserved, 16(4), 615-622.

Cılga, İ. (2009). Sosyal dışlanmanın dinamiği, bilimin, mesleğin dışlanması ve öngörüler. Toplum ve Sosyal Hizmet, 20 (2), 7-26.

Crane, M., Warnes, A. M., Fu, R. (2006). Developing homelessness prevention practice: Combining research evidence and professional knowledge. Health and Social Care in the Community, 14 (2), 156-166.

Demir, G. (2017). Yoksulluk sorunu bağlamında halk kütüphanelerinin rolünün sorgulanması: Kuramsal bir yaklaşım. Akademi Sosyal Bilimler Dergisi, 1(3), 47-68.

Doherty, J. (2001). Gendering homelessness. In Edgar, B. and Doherty, J. (Eds.), Women and Homelessness in Europe; Pathways, Services and Experiences (pp.9-20). Bristol: The Polity Press.

Erbay, E., (2013), Evsizler, Sokakların Görünmeyen Yüzleri, Ankara: Sabev Yayınları.

Fitzgerald, M. D., (1999). To live and to learn: Homeless youth, literacy, education and career. Halifax: Phoenix Youth Programs.

Hagan, J. and McCarthy, B. (1998). Mean Streets: Youth crime and homelessness. Cambridge: Cambridge University Press.

Hecht, L., Coyle, B. (2001). Elderly homeless. American Behavioral Scientist. 45(1),66-79.

Helvie, C.O. (1999). Homelessness in different countries. In Carl O. Helvie and Wilfried Kuntsmann (Eds.), Homelessness in the United States, Europa and Russia. A copmparative perspective. Greenwood publishing, USA.

Herman, D. B., Susser, E. S., Struleninlg, E. L., Link, B. L. (1997). Adverse childhood experiences: Are they risk factors for adult homelessness? American Journal of Public Health, 1 (87), 2, 249-255.

Hwang, S. W. (2001). Homelessness and health. Canadian Medical Association Journal, 164 (1), 229-233. 
Işıkhan, V. (1995) Evsizlere yönelik sosyal hizmet uygulamaları. Sosyal Hizmet Sempozyumu'95 30. Yılında Sosyal Hizmet ve Geleceğe Yöneliş, 22-24 Kasım, Ankara

Işıkhan, V. (2002). Kentlerin Gölgesinde Yaşayan Evsizler. Ankara: Kardelen Ofset.

İlhan, N. ve Ergün, A. (2010). Evsizler ve toplum sağı̆ğı. Aile ve Toplum, 11(5), 20, 79-90.

Jakub, M., Vágnerová, M., Csémy, L. (2011). Developmental and psychosocial characteristics of young adult homeless in Prague. Procedia - Social and Behavioral Sciences, 30,1888-1893.

Kılıç, T. Y., Yeşilaras, M., Atilla, Ö. D., Toker, I., Temizyürek, Z. (2015). Homeless patients in the emergency department. Journal of Academic Emercency Medeicine. 14(2), 70-74.

Levitt, A. J., Culhane, D. P., DeGenova, J., O'Quinn, P., Bainbridge, J. (2009). Health and social characteristics of homeless adults in Manthattan who were chronically or not chronically. Psychiatric Services, 60(7), 978-983.

Özdemir, U. (2010). Evsizlik ve Evsizlere Genel Bir Bakış. Toplum ve Sosyal Hizmet, 21(2), 77-88.

Plumb, J. D. (2000). Homelessness: Reducing health disparities. Canadian Medical Association Journal ,163 (2), 172-173.

Quilgar, D. and Pleace, N. (2010). Meeting the Needs of Households at Risk of Domestic Violence in England: The Role of Accommodation Housing-Related Support Services. London: Communities and Local Government.

Ringwalt, C. L., Greene, J. M., Robertson, M., McPheeters, M. (1998). the prevalence of homelessness among adolescents in the United States. American Journal of Public Health, 88 (9), 1325-1329.

Roos, L. E., Mota, N., Afifi, T. O., Katz, L. Y., Distasio, J., Sareen, J. (2013). Relationship between adverse childhood experiences and homelessness and the impactof axis I and II disorders. American Journal of Public Health, 103(2), 275-281.

Salit S. A., Kuhn, E. M., Hartz A. J., Vu, J. M., Mosso A. L. (1998). Hospitalization costs associated with homelessness in New York City. N Engl J, 338:1734-1740

Shinn, M., Weitzman, B.C., Stojanovic, D., Knickman, J.R., Jimenez, L., Duchon, L., James, S., Krantz, D.H. (1998). Predictors of homelessness among families in New York City: From Shelter Request to Housing Stability. American Journal of Public Health, 88 (11), 1651-1657. 
Susser, E., Moore, R., Link, B. (1993). Risk factors for homelessness. Epidemiologic Reviews, 15(2), 546-556.

Türkcan, S. ve Türkcan, A. (1996). Psikiyatri ve Evsizlik: Bir gözden geçirme çalışması. Düşünen Adam, 9(4): 8-14.

U.S. Conference of Mayors. (2005). A Status Report on Hunger and Homelessness in America's Cities: 2004. Available at www.usmayors.org.

U.S. Conference of Mayors. (2018). A Status Report on Hunger and Homelessness in America's Cities: $2018 . \quad$ Available at https://endhomelessness.atavist.com/mayorsreport2016.

U.S. Department of Housing and Urban Development. (2018). The 2018 Annual Homeless Assessment Report (AHAR) to Congress, Available at, https://www.hudexchange.info/resources/documents/2018-AHAR-Part-1.pdf.

Yıldıım, N. ve Yıldırım, K. (2014). Homelessness within social change. Mediterranean Journal of Social Sciences. 5 (22), 418-432.

Yılmaz, M. (2012). Küreselleşme ve kentsel yoksulluk: Sosyolojik bir perspektif. Insan ve Toplum Bilimleri Araştırmaları Dergisi, 1(4), 257-287.

Young, S. (Ed.) (2010). Gender perspectives on homelessness. Homelessness in EuropeThe Magazine of FEANTSA. Spring, Brussels: FEANTSA. 